\title{
Autoimmune polyglandular syndrome type II presenting as subacute combined degeneration of spinal cord: a neuroendocrinology crossroad
}

\author{
PRATEEK BAPAT, SUMAN KUSHWAHA, CHIRAG GUPTA, KIRANGOWDA R, VAIBHAV SETH
}

Department of Neurology, Institute of Human Behaviour and Allied Sciences, Dilshad Garden, Delhi, India, PIN-110095

\begin{abstract}
Introduction: Autoimmune polyglandular syndrome (APS) is a condition having multiple endocrine abnormalities. It is divided into three types depending on the involvement of various endocrinopathies. It is also associated with other systemic involvement. The basic pathophysiology of this syndrome revolves around autoimmunity.

Case presentation: We discuss the case of a 50-year-old gentleman who presented to us in emergency with subacute onset progressive weakness of both lower limbs followed by upper limbs. On examination, patient was confused and disoriented. General examination findings include hypotension, pallor, facial puffiness and vitiligo. Neurological examination revealed spasticity and motor weakness in all four limbs with extensor planter response. Sensory examination during hospital course revealed posterior column involvement. Laboratory and radiological investigations confirmed subacute combined degeneration of spinal cord secondary to pernicious anaemia, Addison's disease and autoimmune thyroid disease. The final diagnosis of autoimmune polyglandular syndrome type II was made after fulfilment of the required criteria.

Conclusion: Autoimmune polyglandular syndrome type II can rarely present to neurologist as subacute combined degeneration of spinal cord. This syndrome and its systemic association should be kept in mind in order to reach the final diagnosis.
\end{abstract}

Key words: Autoimmune polyglandular syndrome type II, subacute combined degeneration of spinal cord, vitamin B12 deficiency, pernicious anemia, neuroendocrinology.

\section{INTRODUCTION}

Autoimmune polyglandular syndrome (APS), also called autoimmune polyendocrine syndrome, leads to dysfunction of multiple endocrine glands along with several nonendocrine involvement like neurological, dermatological, haematological, gastrointestinal and other disorders, all having an autoimmune pathogenesis in common.

APS type I includes at least two out of the following diseases: mucocutaneous candidiasis, hypoparathyroidism and Addison's disease. APS type II (Schmidt's or Carpenter's Syndrome) is characterized by the presence of at least two out of three endocrinopathies: Addison's disease, autoimmune thyroid disease and type I diabetes mellitus [1]. A third subtype has been described, which contrary to type I and II does not involve the adrenal gland.

This is a first case report of a patient who presented with sub acute combined degeneration of spinal cord (SACD) and ultimately diagnosed to have APS type II.

\section{CASE REPORT}

A 50-year-old male patient born out of nonconsanguineous marriage with no co-morbidities presented to emergency with four weeks history of subacute onset weakness of bilateral lower limbs progressing to bilateral upper limbs associated with tingling and numbness in all four extremities along with urinary retention and constipation. There was no history of abdominal surgery and addictions. Family history was negative. Dietary habits include both vegetarian and non-vegetarian food.

On general examination, patient had blood pressure of 90/60 with pallor and puffiness of face. Patient also had alopecia, hyperpigmentation over face, hyperpigmented nipples (See Fig. 1, Images A and B) and vitiligo on both legs (See Fig. 1, Image C). 


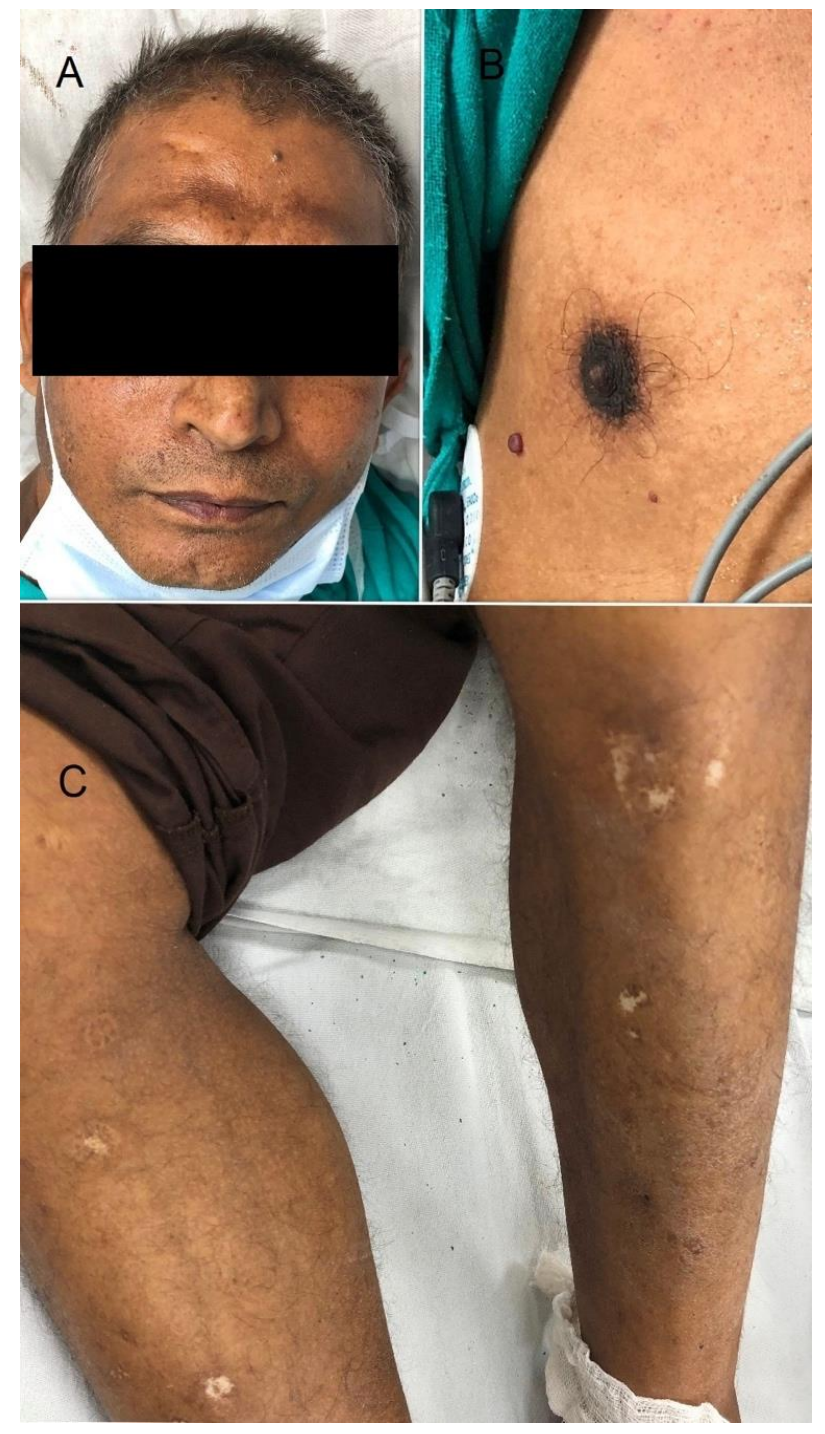

Fig. 1. Skin manifestations.

A. Skin hyperpigmentation over face

B. Hyperpigmented nipple

C. Vitiligo patches over both legs

On neurological examination, the patient was conscious but confused and disoriented to time, place and person. Fundus and cranial nerves were normal. Motor examination revealed spasticity in all four limbs and quadriparesis (strength in both upper limbs $-3 / 5$ and both lower limbs - 0/5) with total areflexia and bilateral extensor planter response. Sensory examination on admission could not be done, but later on revealed loss of vibration sense below clavicle and loss of joint position in all four limbs. Superficial sensation was normal. Cerebellar and meningeal signs were absent. Other systemic examination was normal.
Routine blood investigation revealed pancytopenia with macrocytic anaemia (Hemoglobin - 7.3 gm \%, white blood count $4,160 / \mathrm{mm}^{3}$, platelet - 1.4 lakhs $/ \mathrm{mm}^{3}$ ), hyponatremia $(125 \mathrm{mmol} / \mathrm{L})$, normal potassium. Fasting blood sugar was $152 \mathrm{mg} / \mathrm{dl}$ and post prandial was $154 \mathrm{mg} / \mathrm{dl}$ with glycated haemoglobin of $4.1 \%$. CSF study was normal with absence of oligoclonal bands and normal IgG index. Viral markers (HIV, HBsAg, anti-HCV) by ELISA were negative. FT3=1.9 $(2-4.4 \mathrm{pg} / \mathrm{ml})$, FT4=1.3 $(0.93-1.7 \mathrm{ng} / \mathrm{dl})$, $\mathrm{TSH}=10.7 \quad(0.27-4.2 \mu \mathrm{IU} / \mathrm{ml})$. Anti-TPO antibody was positive. Serum vitamin B12 level was $65(200-835 \mathrm{pg} / \mathrm{ml})$ and folic acid $>20(2-20 \mathrm{ng} / \mathrm{ml})$. Further investigating the cause of reduced vitamin B12 levels prompted us do to intrinsic cell antibody and parietal cell antibody which came to be positive. Because of persistent hypotension and hyponatremia paired cortisol and ACTH were done at 8 am and showed cortisol levels to be $3.2(5-25 \mu \mathrm{g} / \mathrm{dl})$ and ACTH levels to be $61.2(0-46 \mathrm{pg} / \mathrm{ml})$. Antibody against 21-hydroxylase, islet cell components (Insulin, GAD65, IA-2, ZnT8) were not done owing to non-availability. However, signs of insulin resistance were present in the form of abdominal obesity with waist circumference of $92 \mathrm{~cm}$ and BMI of $25.9 \mathrm{~kg} / \mathrm{m}^{2}$, elevated triglyceride level-225 mg/dl and low HDL-36 $\mathrm{mg} / \mathrm{dl}$ level. Chest X-ray and electrocardiogram were normal. Ultrasound abdomen suggested fatty liver. Nerve conduction study showed sensorimotor axonal type of polyneuropathy. Brain MRI revealed non-specific hyperintense foci involving the cerebral white matter (See Fig. 2, Image A). MRI axial section of spinal cord shows "inverted V" or "inverted rabbit ears" sign (See Fig. 2, Image B). Whole spine MRI was suggestive of SACD without any contrast enhancement (See Fig. 2, Image $\mathrm{C}$ and $\mathrm{D}$, contrast images not provided). MRI orbit revealed no abnormality. Test for aquaporin-4 and myelin oligodendrocyte glycoprotein antibody were negative.

Patient was managed with parenteral vitamin B12 and folic acid supplementation, iv hydrocortisone with diabetic diet and short acting regular insulin. Patient improved with respect to its blood pressure and sensorium and later levothyroxine 12.5 microgram per day was added to its treatment and patient started showing improvement and is in our follow up. 


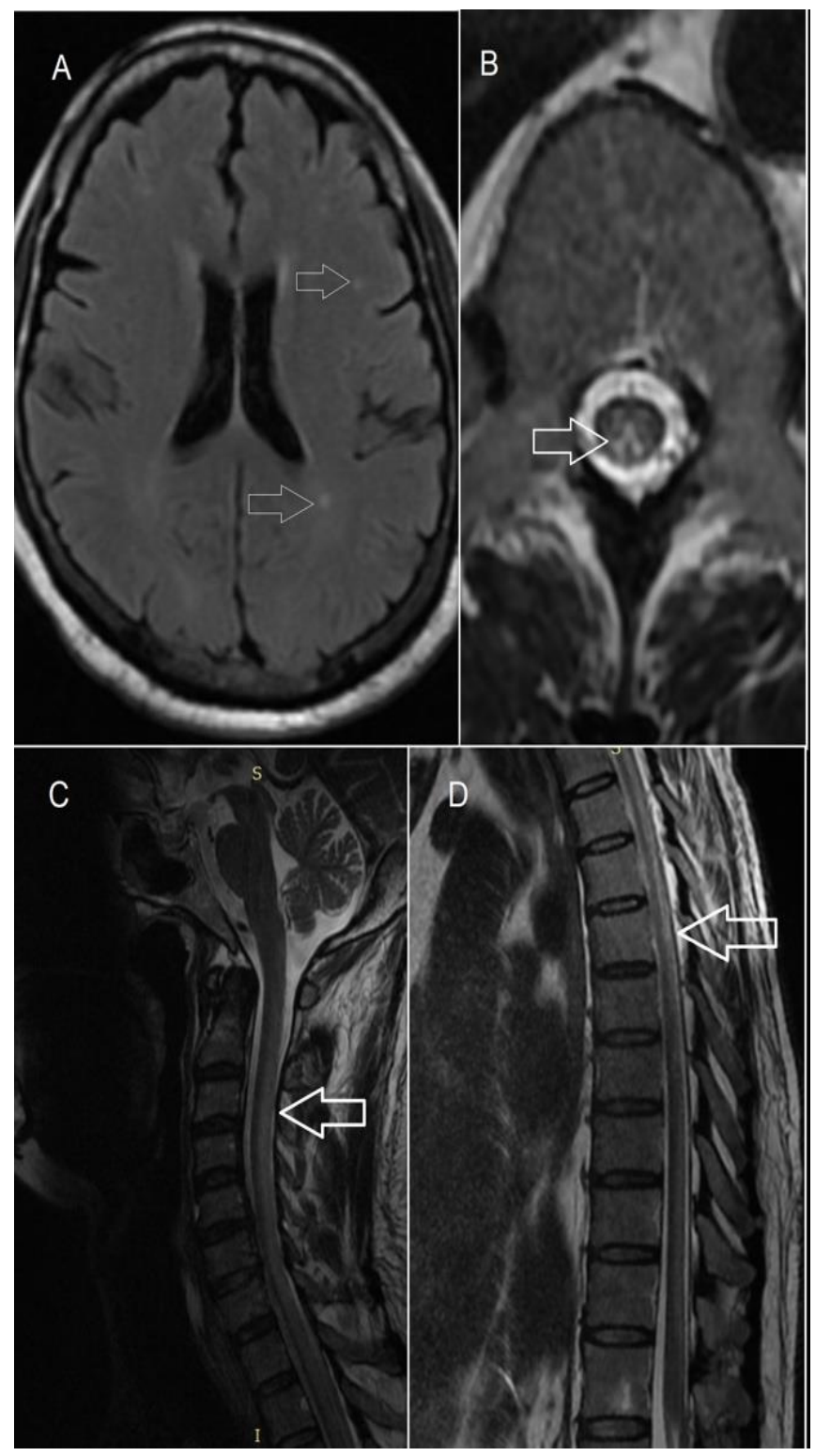

Fig. 2. Brain and spine MRI.

A. T2/FLAIR non-specific hyperintense foci in cerebral white matter.

B. Axial section of spinal cord shows bilateral paired areas of T2 hyperintensity seen as "inverted V" or "inverted rabbit ears" in dorsal column.

C. Cervical spine MRI showed long segment T2 hyperintensity involving dorsal aspect of spinal cord.

D. Thoracic spine MRI showed long segment T2 hyperintensity involving dorsal aspect of spinal cord.

\section{DISCUSSION}

The prevalence of APS type II is reported to be 1.4 to 4.5 cases per 100,000 persons [2]. It has a polygenic genetic predisposition and usually manifests between 30 to 40 years of age, with male to female ratio of 1:3 [3]. First-degree relatives of patients with APS type II are at increased risk of autoimmune disorders. It was described first as Schmidt's Syndrome in 1926 [4]. It is associated with specific HLA DR3 and DR4 haplotypes and with the class II HLA alleles DQ2 and DQ8, also strongly linked to celiac disease [5].

Percentage wise distribution in APS type II: Addison's disease(100\%), autoimmune thyroid disease (69-82\%), type I diabetes mellitus (30-52\%). Hypogonadism seen in 4-9\% cases. Nonendocrine manifestations are celiac sprue, pernicious anaemia (4.5-11\%), vitiligo (4.5-11\%), alopecia $(1-4 \%)$, myasthenia gravis $(<1 \%)$, hypophysitis $(<1 \%)$ [6]. Other neurological disorders described are chronic inflammatory demyelinating polyneuropathy, stiff man syndrome, cerebellar ataxia, parkinson's disease [7].

In this case, we had a male patient who presented with SACD secondary to pernicious anaemia as a first clinical presentation of APS type II. The uniqueness of the case lies in the fact that a neurological manifestation led to masquerading of an underlying endocrine disorder. To our knowledge after searching the literature, this is the first of a kind initial presentation of APS type II and hence we are reporting this case.

\section{CONCLUSION}

Pernicious anaemia is one of the common causes of cobalamin deficiency which leads to SACD. As a neurologist, on encountering an autoimmune cause of vitamin B12 deficiency, one should suspect and workup further for any other co-existing autoimmune diseases. This case highlights a syndrome which mostly presents to an endocrinologist but rarely neurological symptoms can be its presenting manifestation.

Introducere: APS (sindrom poliendocrin autoimun) se asociază cu multiple anomalii endocrine. El există sub 3 forme și asociază și alte afectări sistemice.

Prezentare de caz: Prezentăm cazul unui pacient de 50 de ani ce s-a prezentat cu debut lent de slăbicune de membre inferioare și superioare. Pacientul era confuz și dezorientat. Prezenta spasticitate, vitiligo şi deficit motor, alături de afectare de cordon posterior medular. Analizele de laborator au confirmat degenerarea secundară 
a cordonului medular datorat anemiei pernicioase, sindromului Addison și tiroiditei autoimune. Diagnosticul final de APS tip II a fost pus.

Concluzii: APS tip 2 se poate prezenta la neurolog inițial. Trebuie reținut acest diagnostic diferențial.

Correspondence to: Prateek Bapat, Department of Neurology, Institute of Human Behaviour and Allied Sciences, Dilshad Garden, Delhi, India, PIN-110095.

Email: prateekbapat1524@gmail.com

\section{REFERENCES}

1. HUSEBYE ES, ANDERSON MS, KÄMPE O. Autoimmune Polyendocrine Syndromes. N Engl J Med. 2018 Mar 22; 378(12):1132-1141.

2. CHEN QY, KUKREJA A, MACLAREN NK. The Autoimmune Polyglandular Syndromes. In: Endocrinology. W.B. Saunders, Philadelphia, 2001:587-99.

3. SCHATZ DA, WINTER WE. Autoimmune polyglandular syndrome. II: Clinical syndrome and treatment. Endocrinol Metab Clin North Am. 2002 Jun; 31(2):339-52.

4. SCHMIDT MB. Eine biglandulare Erkrankung (Nebennieren und Schilddruse) bei Morbus Addisonii. Verh Dtsch Ges Pathol. 1926; 21:212-221.

5. ROBLES DT, FAIN PR, GOTTLIEB PA, EISENBARTH GS. The genetics of autoimmune polyendocrine syndrome type II. Endocrinol Metab Clin North Am. 2002 Jun; 31(2):353-68, vi-vii.

6. BETTERLE C, DAL PRA C, MANTERO F, ZANCHETTA R. Autoimmune adrenal insufficiency and autoimmune polyendocrine syndromes: autoantibodies, autoantigens, and their applicability in diagnosis and disease prediction. Endocr Rev. 2002 Jun;23(3):327-64. Erratum in: Endocr Rev. 2002 Aug; 23(4):579.

7. PETER A. GOTTLIEB, AARON W. MICHELS. Autoimmune Polyendocrine Syndromes. In: Harrison's Principles of Internal Medicine, McGraw-Hill Education, New York, 2018:382:2756.

Received $27^{\text {th }}$ July 2021 